Meta

Journal des traducteurs

Translators' Journal

\title{
De-feminised Sherlock Holmes' Woman: A Failed Attempt
}

\section{Hiroko Furukawa}

Volume 60, numéro 2, août 2015

$60^{\mathrm{e}}$ anniversaire. Les horizons de la traduction : retour vers le futur

$60^{\text {th }}$ Anniversary. Translation's Horizons: Back to the Future

60mo aniversario. Los horizontes de la traducción: regreso al futuro

URI : https://id.erudit.org/iderudit/1032884ar

DOI : https://doi.org/10.7202/1032884ar

Aller au sommaire du numéro

Éditeur(s)

Les Presses de l’Université de Montréal

ISSN

0026-0452 (imprimé)

1492-1421 (numérique)

Découvrir la revue

Citer ce document

Furukawa, H. (2015). De-feminised Sherlock Holmes’ Woman: A Failed

Attempt. Meta, 60(2), 333-333. https://doi.org/10.7202/1032884ar d'utilisation que vous pouvez consulter en ligne.

https://apropos.erudit.org/fr/usagers/politique-dutilisation/ 


\title{
De-feminised Sherlock Holmes' Woman: A Failed Attempt
}

\author{
Hiroko Furukawa \\ Tohoku Gakuin University, Sendai, Japan \\ f.hiroko@mail.tohoku-gakuin.ac.jp
}

In my previous studies, it is claimed that female characters' speech tends to be overly feminised in Japanese translations, and the convention has functioned as a mediator of gender ideology in Japanese society. Thus, it is suggested to 'de-feminise' their speech as a feminist translation strategy as opposed to the ideologically encouraged convention.

In practice, however, it seems difficult for de-feminising translation to be realised because of the book market, publishers and readers' expectations. Thus, this paper will explore an actual case which failed in neutralising the female characters' speech due to the audience or translator's expectations (or both). To do so, this research takes two steps. First, Effie's speech in shadow translations and the accepted version of The Yellow Face (Sherlock Holmes 1893/2008, translated by Yu Okubo) will be analysed qualitatively and quantitatively to see how far the shadow translations are neutralised and the accepted version is feminised. The analysis focuses on sentence-final particles which are regarded as the most representative female language use. Second, the translator will be interviewed to explore what happened in the translation process, and how translational norms in the Japanese literary system affected him in practice. Through the investigation, this paper hopes to describe the translational phenomena and norms in Japanese translation from a feminist perspective.

PhD in Literary Translation (University of East Anglia, UK, 2011). My main research interests are translation theories (esp. Polysystem Theory, DTS, Relevance Theory and Feminist Theory), language and gender ideology, and translation genres and their position. My recent publication includes 'A Feminist Woman with a Given Female Language: A Contradictory Figure in the Japanese Translation of Margaret Atwood's The Edible Woman' (Babel, 2012), 'Representations are Misrepresentations: The Case of Cover Designs of Banana Yoshimoto's Kitchen' (TTR, 2013), 'Disaster and Relief: The 3.11 Tohoku and Fukushima Disasters and Japan's Media Industries' (International Journal of Cultural Studies, 2015), and 'Intracultural Translation into an Ideological Language: The Case of the Japanese Translations of Anne of Green Gables' (Neohelicon, fothcoming). 